\title{
Starch Accumulation and Photosynthesis in Leaves of Young Peach Trees Grown under Different Levels of Nitrogen Application
}

\author{
Naosuke Nii, Maki Kato, Yuki Hirano and Tooru Funaguma \\ College of Agriculture, Meijo University. Tempaku, Nagoya 468
}

\begin{abstract}
Summary
The effects of the different levels of nitrogen application on leaf characteristics including starch accumulation and photosynthesis were determined in two-year-old peach trees (Prunus persica (L.) Batsch. cv. Ohkubo). The nitrogen content on dry weight basis in the leaves was the lowest in the zero-nitrogen plot $(\mathrm{N}-0): 2.5 \%$, and increased with increasing the nitrogen application; $1.5 \mathrm{~g}$ plot $(\mathrm{N}-1.5), 2.9 \% ; 3.0 \mathrm{~g}$ plot $(\mathrm{N}-3.0), 3.4 \%$; and $6.0 \mathrm{~g}$ plot $(\mathrm{N}-6.0), 3.8 \%$. Compared with those in higher nitrogen plots, the leaves on $\mathrm{N}-0$ plot were thinner, smaller, and yellowish: chlorophyll content per unit leaf area was lower at decreasing levels of nitrogen application. The starch content in the chloroplasts of the leaves from the $\mathrm{N}-0$ plot was higher than those from plots in which nitrogen was added. Amylase activity, which was the lowest in the leaves of $\mathrm{N}-0$ plot, was in inverse proportion to the starch accumulation; amylase activity in leaves from the $\mathrm{N}-3.0$ and $\mathrm{N}-6.0$ plots, which contained less starch content, was higher. In the chloroplasts of the leaves from the $\mathrm{N}-0$ plot, chloroplast nucleoids were localized at the periphery of the plastids, whereas they were evenly distributed in chloroplasts of leaves with higher nitrogen contents. The photosynthetic rate per unit leaf area was the lowest in N-0 plot, and increased with nitrogen application: the difference, however, between nitrogen plots was not significant.
\end{abstract}

\section{Introduction}

The reduction of the photosynthetic activity under conditions where the sink capacity on the shoots was decreased as a result of defruiting and increased levels of carbohydrates in leaves (Noel, 1970; Milford and Pearman, 1972; Thorne and Koller, 1974; Nafziger and Koller, 1976). We have already reported that the chloroplast compartment including thylakoid layers, which are important organs for photosynthesis, changes easily with the starch grain size in chloroplasts (Nii, 1987, 1989, 1992, 1993; Nii and Kuroiwa, 1988). Furthermore, when the starch grains accumulated in the chloroplasts, chloroplast nucleoids were detected at the peripheral zone in the chloroplasts ( $\mathrm{Nii}$ and Kuroiwa, 1988; Nii, 1992). Although it has not been discussed whether the distribution of chloro. plast nucleoids influence the photosynthetic rate, Kuroiwa et al. (1981) suggested that the develop-

Received for publication 31 May 1993. ment of thylakoidal lamellae was related to the division and distribution of chloroplast nucleoids. With increasing starch size in chloroplasts, the photosynthetic rate of fruit tree leaves decreased (Nii, 1987, 1992). Other workers in this field have found little or no correlation between the rate of photosynthesis and the level of leaf assimilate was not definitive (Neals and Incoll, 1968; Carmi and Shomer, 1979; Daie, 1985). However, we believe that it is important to study the changes in starch content in chloroplasts of photosynthetically active leaves of fruit trees.

The starch accumulation in the leaf chloroplast is influenced by many different factors in relation to environmental and physiological conditions. It has already been reported that starch accumulation in rice leaves increased dramatically with nitrogen deficiency (Chonan et al., 1977). When the level of the nitrogen application was lower for kiwi seedlings, starch content in leaves increased, while chlorophyll content clearly decreased and the leaf color became yellow (DeJong et al., 1984). 
The photosynthetic rate $(\mathrm{Pn})$ also decreases with deficiency of mineral fertilizer, and specifically the effect of nitrogen levels on the $\mathrm{Pn}$ is most important because the nitrogen is main structural element in chlorophyll (DeJong, 1982, 1983; DeJong et al., 1984). However, the relationship between photosynthesis and starch accumulation accompanying chloroplast ultrastructural changes has not been determined with respect to nitrogen application in fruit trees.

The present experiment was designed to determine the effect of the different leaf $N$ levels on starch accumulation in relation to amylase activity and the photosynthetic rate in peach trees.

\section{Materials and Methods}

\section{Plant materials}

In 1992, two-year-old nonbearing peach trees (Prumus persica (L.) Batsch cv. Ohkubo) grown in $30-\mathrm{cm}$ basket covered with black polypropylene film were supplied with different levels of nitrogen fertilizer as $\mathrm{NH}_{4} \mathrm{NO}_{3}$ : zero- nitrogen per pot $(\mathrm{N}-0)$. $1.5 \mathrm{~g} / \mathrm{pot}(\mathrm{N}-1.5), 3.0 \mathrm{~g} / \mathrm{pot}(\mathrm{N}-3.0)$, and 6.0 $\mathrm{g} /$ pot $(\mathrm{N}-6.0)$. Other minerals applied were: $\mathrm{Ca}$ $\left(\mathrm{H}_{2} \mathrm{PO}_{4}\right)_{2} ; 0.68 \mathrm{~g}, \mathrm{~K}_{2} \mathrm{SO}_{4} ; 0.74 \mathrm{~g}, \mathrm{MgSO}_{4} \cdot 7 \mathrm{H}_{2} \mathrm{O}$; $3.37 \mathrm{~g}$ per pot. Fertilizers were applied on March 15 and May 15. Each treatment consisted of 15 plants.

Leaves at the 5-7th nodal positions from the base on the current shoot were used to determine average leaf area and dry weight per unit leaf area, chlorophyll content, carbohydrate and mineral contents and amylase activity, along with anatomical observations. Samples of leaves were harvested at 9:00 a.m. on June 18 .

\section{Carbohydrate and mineral analysis}

After drying the leaves by a vacuum freeze drier, the sample was reduced to powder. Sugars were extracted with $80 \%$ ethanol at $80^{\circ} \mathrm{C}$ and the starch in the alcohol insoluble solids digested by glucoamylase. Total and solubilized sugars were determined separately by the anthrone method. The nitrogen content was measured by the Kjel. dahl method, phosphorus by reacting with ammonium molybdate, potassium by flame spectrophotometry, and calcium and magnesium by atomic absorption spectrophotometry method.

\section{Amylase activity}

Leaf samples were stored at $-21^{\circ} \mathrm{C}$ until they were assayed enzymatically. One gram fresh weight of leaves was homogenized with $4 \mathrm{ml}$ of 10 $\mathrm{mM}$ tris. $\mathrm{HCl}$ buffer, $\mathrm{pH} 7.0$, under $4^{\circ} \mathrm{C}$. After centrifugation at $14,000 \mathrm{rpm}$ at $4^{\circ} \mathrm{C}$ for $15 \mathrm{~min}$, the supernatant was dialyzed against the same buffer at $4^{\circ} \mathrm{C}$ for $4 \mathrm{hr}$. The dialysate was tested for amy lase activity.

Amylase activity as a soluble type was assayed by determining the amount of glucose produced from starch by the Somogyi method and by determination of the remaining starch content after enzyme treatment using the I-KI method. For the amylase assay, $0.25 \mathrm{ml}$ of $0.2 \mathrm{M}$ tris-acetic acid buffer ( $\mathrm{pH} 6.0$ ) and $0.4 \mathrm{ml}$ of $2 \%$ soluble starch, $0.05 \mathrm{ml}$ of distilled water, and $0.1 \mathrm{ml}$ of the sample were mixed. The reaction was completed at $37^{\circ} \mathrm{C}$ for $30 \mathrm{~min}$.

The resulting reducing sugars were measured by the Somogyi method with glucose as standard; and the remaining starch in the reaction mixture was estimated with the I-KI method.

For reducing sugar assay, one unit of enzyme was defined as the amount of enzyme that produces on equivalent to $1 \mu \mathrm{mol}$ of glucose per min under the above conditions. For the residual starch assay, one unit of enzyme was defined as that which decreases the OD 0.1 unit per min at $580 \mathrm{~nm}$ under the above conditions.

Anatomical observation using light microscopy (LM) and transmission electron microscopy (TEM)

For anatomical observation, the central area of the lamina was cut with a razor blade and fixed at room temperature for $2 \mathrm{hr}$ with $2 \%$ glutaraldehyde in $0.1 \mathrm{M}$ cacodylate buffer $(\mathrm{pH}$ 7.2) followed by $2 \%$ osmic acid for $2 \mathrm{hr}$. The fixed specimens were dehydrated through a graded ethanol-acetone series and embedded in Spurr resin (Spurr, 1969). For LM, thin sections $(1.5 \mu \mathrm{m})$ were stained with methylene blue and I-KI solution to observe starch accumulation and mesophyll development. For TEM. the ultrathin sections were stained with uranyl acetate followed by lead citrate (Reynolds, 1963) and examined with a JEOL 100CX electron microscope. 
4'6-diamidino.2-phenylindole (DAPI) staining of chloroplast nucleoids

To observe the localization of the chloroplast nucleoids (ct-nucleoids), the mesophyll tissue was separated by gentle maceration (Kuroiwa and Suzuki, 1980). The organization and arrangement of ct-nucleoids in the chloroplasts were studied with a light microscope using the fluorescent probe DAPI.

\section{Determination of photosynthetic rate}

The photosynthetic rate (as measured by $\mathrm{CO}_{2}$ assimilation) was measured from $7: 00$ to $13: 00$ hr on June 18 and 21 with a Koito portable $\mathrm{CO}_{2}$ gas analyzer (KIP-85SC). Pn measurements were made on two of the 5-7th fully expanded leaves.

\section{Results and Discussion}

Leaf characteristics, i.e., leaf area, leaf dry weight per unit leaf area, chlorophyll content, are shown in Table 1. Mean leaf area was the smallest on N-0 plant. Leaf size increased with increasing nitrogen levels. However, no difference in leaf size was detected between $\mathrm{N}-1.5$ and $\mathrm{N}-6.0$ plants. Compared with leaves from the $\mathrm{N}-3.0$ and $\mathrm{N}-6.0$ plots, those from the $\mathrm{N}-0$ and $\mathrm{N}-1.5$ plots were thinner. Current season's shoots were markedly shorter in $\mathrm{N}-0$ plants: average shoot length of $\mathrm{N}-0, \mathrm{~N}-1.5, \mathrm{~N}-3.0$, and $\mathrm{N}-6.0$ was $83.8,116.3$, 142.6 and $131.4 \mathrm{~cm}$, respectively. The chlorophyll content in $\mathrm{N}^{-0}$ plants was the lowest among the treatments. With increasing levels of nitrogen application, the chlorophyll content increased. The difference between $\mathrm{N}-0$ and $\mathrm{N}-1.5$ plants was distinctly visible.

With decreasing nitrogen application levels, nitrogen content in leaves decreased, parallel to ni- trogen application levels (Table 2). P, K, Ca and $\mathrm{Mg}$ levels in leaves did not differ among treatments.

The width of mesophyll tissues were thinner in $\mathrm{N}-0$ and $\mathrm{N}-1.5$ plants which is attributed to reduced development of palisade and decreased spongy cell size (Fig. 1). The size of starch grain in the chloroplasts of $\mathrm{N}-\mathrm{O}$ plants as determined by I-KI staining method and transmission electron microscopy was the largest among treatments (Figs. 1 and 2). Starch accumulation in the chloroplasts estimated by the I-KI method paralleled that determined by analytical method (Table 3). The starch content in leaves of $\mathrm{N}-\mathrm{O}$ was the highest, $5.66 \%$, compared with $\mathrm{N}-1.5 ; 4.83 \%, \mathrm{~N}-3.0$; $3.10 \%, \mathrm{~N}-6.0 ; 3.38 \%$. Leaves from $\mathrm{N}-0$ plot had almost twice as much starch as those from $\mathrm{N}-3.0$ and $N-6.0$ plots. The difference in the amount of starch accumulated among treatments depended on how much was deposited in the spongy parenchyma and bundle sheath cells (Fig. 1). In contrast, total sugars were the lowest in $\mathrm{N}-0$ plants.

Another main difference among the treatments, as seen in the electron micrographs, was the volume of the chloroplast compartment including

Table 2. Effect of nitrogen application on the mineral concentration $(\% \mathrm{DW})$ in peach leaves.

\begin{tabular}{ccccccc}
\hline $\begin{array}{c}\text { Amount of nitrogen } \\
\text { (g per pot) }\end{array}$ & $\mathrm{N}$ & $\mathrm{P}$ & $\mathrm{K}$ & $\mathrm{Ca}$ & $\mathrm{Mg}$ \\
\hline 0 & 2.46 & 0.19 & 2.51 & 0.99 & 0.29 \\
1.5 & 2.91 & 0.18 & 2.37 & 0.98 & 0.28 \\
3.0 & 3.43 & 0.21 & 2.24 & 1.04 & 0.28 \\
6.0 & 3.83 & 0.20 & 1.93 & 0.85 & 0.25 \\
L. S. D.5\% & 0.27 & NS & NS & NS & NS \\
$1 \%$ & 0.38 & NS & NS & NS & NS \\
\hline
\end{tabular}

Table 1. Effect of nitrogen application on leaf characteristics in 'Ohkubo' peach trees.

\begin{tabular}{cccccc}
\hline \hline $\begin{array}{c}\text { Amount of } \\
\text { nitrogen } \\
(\mathrm{g} \text { per pot })\end{array}$ & $\begin{array}{c}\text { Leaf area } \\
\left(\mathrm{cm}^{2}\right)\end{array}$ & $\begin{array}{c}\text { Dry weight per } \\
\text { unit leaf area } \\
\left(\mathrm{mg} \cdot \mathrm{cm}^{-2}\right)\end{array}$ & $\begin{array}{c}\text { Mesophyll } \\
\text { thickness } \\
(\mu \mathrm{m})\end{array}$ & $\begin{array}{c}\text { Total } \\
\text { chlorophyll } \\
\left(\mu \mathrm{g} \cdot \mathrm{cm}^{-2}\right)\end{array}$ & Chl a per Chl b \\
\hline 0 & 155 & 5.99 & 165 & 28.0 & 2.6 \\
1.5 & 179 & 5.50 & 160 & 36.3 & 2.7 \\
3.0 & 206 & 5.24 & 184 & 39.2 & 2.7 \\
6.0 & 208 & 5.02 & 205 & 44.8 & 2.7 \\
L. S. D.5\% & 29 & NS & 18 & 5.4 & NS \\
$1 \%$ & NS & NS & 26 & 7.5 & NS \\
\hline
\end{tabular}




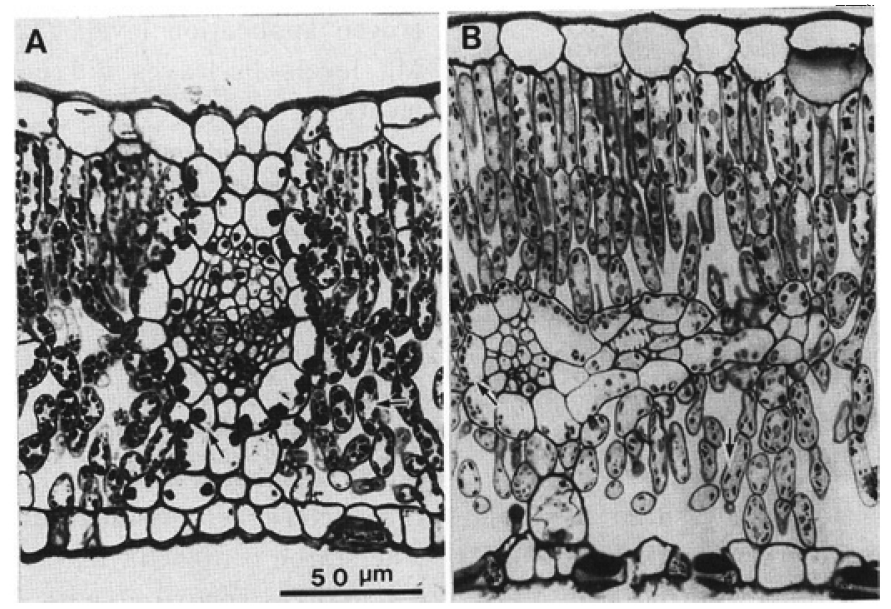

Fig. 1. Effect of nitrogen application on the mesophyll thickness and starch accumulation in peach leaves. A: N-O plot, B: N-6.0 plot. Arrows point to starch grains.
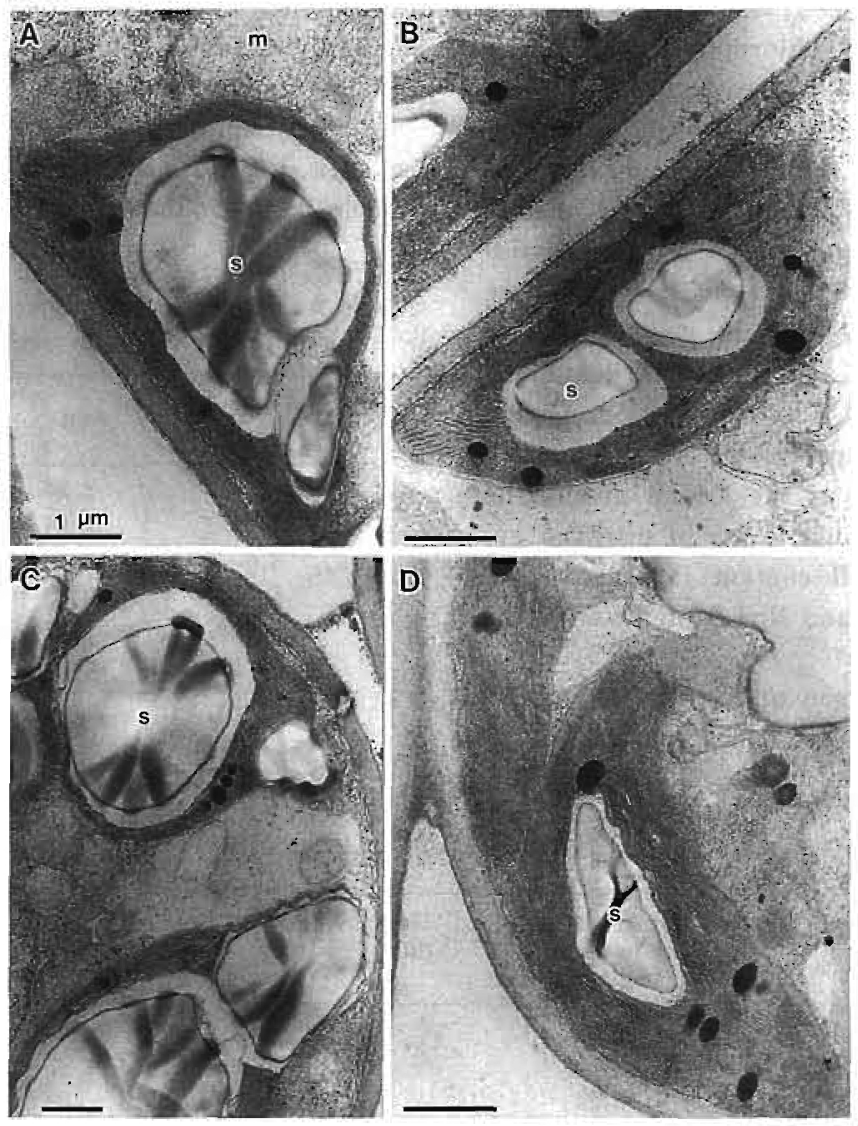

Fig. 2. Electron micrographs of palisade $(A$ and $B)$ and spongy $(C$ and D) parenchyma cells from peach leaves of $N-0$ plot (A and C) and N-6.0 plot (B and D). s: starch grain, m: mitochondria. 
Table 3. Effect of nitrogen application on the carbohydrate content and amylase activity in peach leaves.

\begin{tabular}{ccccc}
\hline \multirow{2}{*}{$\begin{array}{c}\text { A mount of } \\
\text { nitrogen } \\
\text { (g per pot })\end{array}$} & $\begin{array}{c}\text { Total sugars } \\
(\% \mathrm{DW})\end{array}$ & $\begin{array}{c}\text { Starch } \\
(\% \mathrm{DW})\end{array}$ & & \multicolumn{2}{c}{ Amylase activity } \\
\cline { 4 - 5 } 0 & 7.10 & 5.66 & 0.059 & 0.099 \\
1.5 & 8.20 & 4.83 & 0.063 & 0.128 \\
3.0 & 7.43 & 3.10 & 0.113 & 0.187 \\
6.0 & 9.32 & 3.38 & 0.159 & 0.228 \\
L. S. D.5\% & 1.28 & 1.20 & 0.048 & 0.058 \\
$1 \%$ & 1.77 & 1.65 & 0.067 & 0.081 \\
\hline
\end{tabular}

units per $\mathrm{g} \cdot \mathrm{FW}$

thylakoidal layers. The chloroplast of high nitrogen leaves was large (Fig. 2). In the chloroplast of the $\mathrm{N}-0$ plant leaf, the chloroplast compartment and its layers were reduced remarkably, particularly with the presence of much starch in the organelle. The ratio of the chloroplast compartment area per chloroplast, as estimated by electron microscopy, was $26.9 \pm 5.3 \%$ in spongy cells and $36.8 \pm 7.4 \%$ in palisade cells of $\mathrm{N}-0$ plot leaves, and $65.1 \pm 8.1 \%$ in spongy cells and $64.3 \pm 7.1 \%$ in palisade cells of $\mathrm{N}-6.0$ plot. In addition, the size of the chloroplast compartment in N-6.0 plot leaves was two to three fold larger than that of $\mathrm{N}-0$ plot leaves.

A study of the chloroplast ultrastructure of rice revealed that starch accumulation increases in $\mathrm{ni}$ trogen deficient plants (Chonan et al., 1977). Based on electron microscopy, the proportion of starch to chloroplast compartment including thylakoid layers increased during yellowing of zero-nitrogen plants, while the separation of thylakoid layers was not typically detected. In the present experiment, yellowing due to nitrogen deficiency was different from the senescence process on chloroplast ultrastructure (Nii et al., 1988). Thylakoidal systems of yellowish leaves in $\mathrm{N}-0$ plant were still smooth while the volume decreased. Although the volume of the thylakoidal system was reduced in the chloroplast of zero-nitrogen plants, chloroplast and mitochondrial structures seemed otherwise normal. However, we have detected that the amount of Rubisco protein decreased similarly with nitrogen deficiency, fruit thinning, and leaf senescence in relation to the reduction of chloro. plast compartment (in preparation for publication).

Figure 3 shows epifluorescence micrographs of
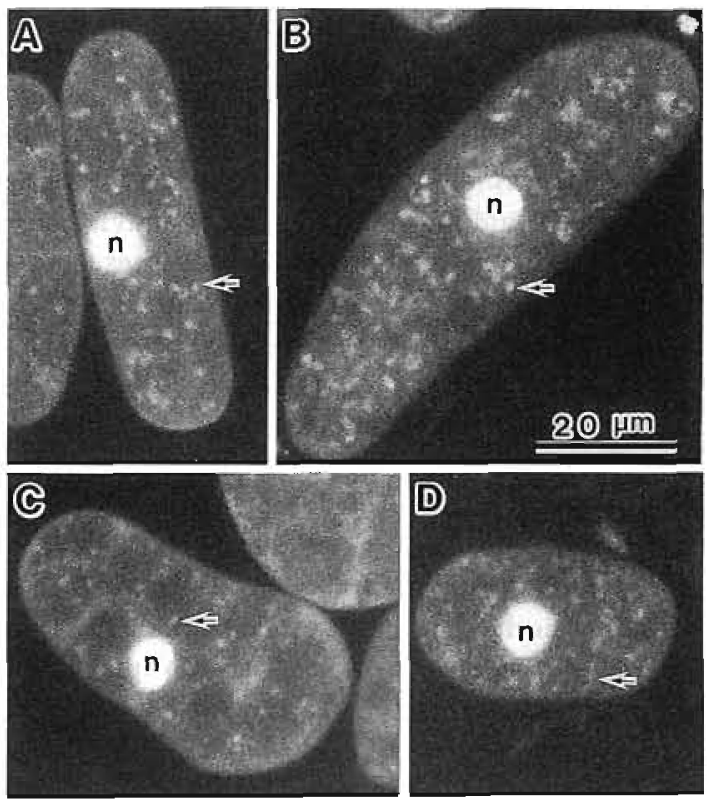

Fig. 3. Fluorescent micrographs revealing the chloroplast nucleoids and the central nucleus ( $n$ ) after DAPI staining of palisade ( $A$ and $B$ ) and spongy $(C$ and $D)$ parenchyma cells from peach leaves. $A$ and $\mathrm{C}$ : N-0 plot. and $\mathrm{B}$ and $\mathrm{D}: \mathrm{N}-6.0$ plot. Arrows point to chloroplast nucleoids.

peach leaf cells stained with fluorochrome DAPI. In the chloroplasts of cells adequately supplied with nitrogen, DAPI fluorescence was well distributed. On the contrary, in the chloroplasts from the nitrogen deficient leaves, DAPI fluorescence was observed only in fine discrete spots along the periphery of the chloroplasts which correspond to the zone of the starch accumulation. These observations are consistent with our previous ones 
(Nii and Kuroiwa, 1988; Nii, 1992).

As leaves turned green with nitrogen, starch accumulation decreased; the rate and amount of starch deposition corresponded to amylase activity (Table 3). The amylase and phosphorylase activities constitute an important event in starch accumulation and degradation. A comparative study of the activities should thus provide a valuable in formation on the phenomenon of starch accumulation. Little work has been carried out on the activity of these key enzymes in peach leaves, especially in relation to various levels of nitrogen fertilization. Although we did not try to assay the phosphorylase activity in the present experiment, amylase activity correlated negatively with starch accumulation in peach leaves. Amylase activity of zero-nitrogen plant leaves which contained much starch was lower than that of higher nitrogen plant leaves which contained less starch. The present result could reveal that amylase activity, normally one of the most functional enzymes on the starch conversion to sugars, increased with and paralleled the increase of starch metabolism.

We are aware of a report which described the effect of flooding the root system on the leaf chloroplast structure and starch accumulation (Wample and Davis, 1983). Reduced starch accumulation in flooded plants may reduce phloem transport as a consequence of a decline in root metabol ism. The mechanism responsible for starch accumulation in nitrogen deficient peach plants remains unclear at this time. However, in fruiting peach plants the starch accumulation in leaves was reduced more than that of nonfruiting plants (Nii, 1993). So firstly, sink capacity may be a principal factor in starch accumulation in leaf chloroplast. In the nitrogen deficient plant tree growth was reduced markedly. Thus, in this plant, sink organs were reduced more than those of plants with adequate nitrogen. Hence, carbohydrate, particularly starch, remained in the leaf chloroplasts in the nitrogen deficient plant. Current shoot growth and carbohydrate consumption are undoubtedly a major sink in young peach trees. With this reduced sink strength and phloem transport, there would be an accumulation of starch in the leaves, as already reported by DeJong et al. (1984).

On June 18 and $21, \mathrm{Pn}$ was generally lower in $\mathrm{N}-0$ plants than it was in plants adequately sup- plied with $\mathrm{N}$ (Fig. 4). There was no significant dif ference in Pn among $\mathrm{N}$-treated plants. These findings indicate that photosynthetic activity decreased as starch accumulated in low nitrogen plants, concurrent to the decrease of the thylakoidal layers in chloroplast. As a result, nitrogen applied plants maintained better photosynthetic machinery. Our observations suggest that, although mitochondria appear normal and intact, chloroplast compartment and thylakoids in zeronitrogen peach plants are displaced due to starch accumulation. Our findings reveal that the photosynthetic activity in fruit tree leaves is proportional, within limits, to leaf $\mathrm{N}$ levels which leads to a direct relationship between the amount of starch accumulated and the decreasing the chloroplast compartment volume which includes the thylakoid layers.

\section{Acknowledgement}

This work was partly supported by grants from
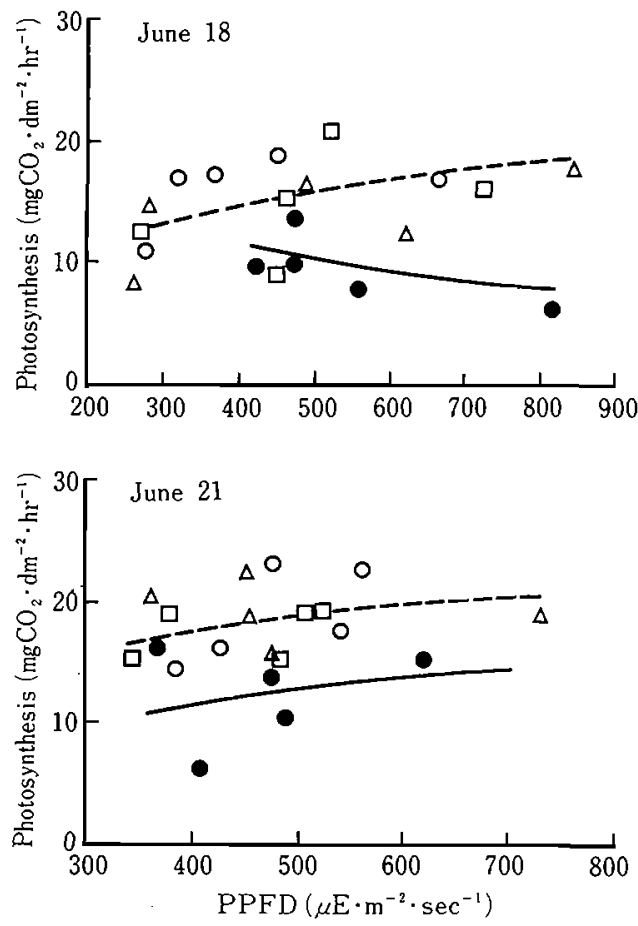

Fig. 4. Light response of $\mathrm{CO}_{2}$ assimilation rate of peach leaves. - $\mathrm{N}-0$ plot, $\mathrm{O}: \mathrm{N}-1.5$ plot, $\Delta: \mathrm{N}-3.0$ plot, $\square$ : N-6.0 plot. 
a Grant-in-Aid for Scientific Research from the Ministry of Education, Science and Culture, Japan.

\section{Literature Cited}

Carmi, A, and I. Shomer. 1979. Starch accumulation and photosynthetic activity in primary leaves of bean (Phaseolus vulgaris L.). Ann. Bot. 44 : 479-484.

Chonan, N., H. Kawahara and T. Matsuda. 1977. Effect of nitrogen application on ultrastructure of the chloroplasts in rice plants. Japan. Jour. Crop Sci. $46: 387-392$.

Daie, J. 1985. Carbohydrate partitioning and metabo. lism in crop. Hort. Rev. $7: 69-108$.

DeJong, T. M. 1982. Leaf nitrogen content and $\mathrm{CO}_{2}$ assimilation capacity in peach. J. Amer. Soc. Hort. Sci. $107: 955-959$.

DeJong, T. M. $1983 . \mathrm{CO}_{2}$ assimilation characteristics of five Prunus tree fruit species. J. Amer. Soc. Hort. Sci. 108: 303-307.

Delong, T. M., A. Tombesi and K. Ryugo. 1984. Photosynthetic efficiency of kiwi (Actinidia chinensis Planch.) in response to nitrogen deficiency. Photosynthetica $18: 139-145$.

Kuroiwa, T. and T. Suzuki. 1980. An improved method for the demonstration of the in situ chloroplast nuclei in higher plants. Cell Struct. Func. 5 : 1.95-197.

Kuroiwa, T., T. Suzuki, K. Ogawa and S. Kawano. 1981. The chloroplast nucleus, distribution, number, size and shape, a model for the multiplication of the chloroplast genome during chloroplast development. Plant Cell Physiol. 22 : 381-396.

Milford, G. F. and I. Pearman. 1972. The relationship between photosynthesis and the concentrations of carbohydrates in the leaves of sugar beet. Photosynthetica $9: 78-83$.

Nafziger, E. D. and H. R. Koller. 1976. Influence of leaf starch concentration on $\mathrm{CO}_{2}$ assimilation in soybean. Plant Physiol. $57: 560-563$.

Neals, T. F. and L. D. Incoll. 1968. The control of leaf photosynthesis rate by the level of assimilate con- centration in the leaf: A review of the photosynthesis. Bot. Rev. 34 : 107-125.

Nii, N. 1987. Anatomical changes including chloroplast structure in citrus leaves under different light conditions in relation to photosynthesis. Sci. Rept., Fac. Agr., Meijo Univ. 23:7-14.

Nii, N. 1989. Fruiting effects on chloroplast structure and starch accumulation in apple leaves. Sci. Rept., Fac. Agr., Meijo Univ. 25 : 35-39.

Nii, N. 1992. Fruiting effects on chloroplast ultrastructure, starch accumulation, and localization of chloroplast nucleoids in peach leaves on the girdled shoots. Sci. Rept., Fac. Agr., Meijo Univ. 28 : 41-48.

Nii, N. 1993. Fruiting effects on leaf characteristics, photosynthesis, and root growth in peach trees. J. Japan. Soc. Hort. Sci. $62: 519-526$.

Nii, N. and T. Kuroiwa. 1988. Anatomical changes including chloroplast structure in peach leaves under different light conditions. J. Hort. Sci. 63 : $37-45$.

Nii, N., S. Kawano, S. Nakamura and T. Kuroiwa. 1988. Changes in the fine structure of chloroplast and chloroplast DNA of peach leaves during senescence. J. Japan. Soc. Hort. Sci. 57 : 390-398.

Noel, A. R. A. 1970. The girdled tree. Bot. Rev. 36 : 162-195.

Reynolds, E. S. 1963. The use of lead citrate at high $\mathrm{pH}$ as an electron opaque stain in electron microscopy. J. Cell Biol. $17:$ 206-212.

Spurr, A. R. 1969. A low viscosity epoxy resin embedding medium for electron microscopy. J. Ultrastructural Res. $26: 31-43$.

Thorne, J. H. and H. R. Koller. 1974. Influence of assimilate demand on photosynthesis, diffusive resistance, translocation and carbohydrate levels of soybean leaves. Plant Physiol. 54:201-207.

Wample, R. L. and R. W. Davis. 1983. Effect of flooding on starch accumulation in chloroplasts of sunflower (Helianthus annuus L.). Plant Physiol. 73 : 195-198. 


\title{
モモの葉内デンプン蓄積ならびに光合成に及ぼす窒素施肥の影響
}

\author{
新居直祐 ·加藤真樹 ·平野友紀 · 船隈 透
}

名城大学㖘学部 468 名古屋市天白区

摘要

モモの未結実樹を用いて，窒素施肥量の差異が葉の 形質, 特に葉緑体中のデンプン蓄積とアミラーゼ活性 ならびに光合成速度に及ぼす影響を調査した，葉内䔔 素含量 (対乾重\%) は無窒素区（N-0区）で $2.5 \%$ と 最も低く, $1.5 \mathrm{~g}$ 区 $(\mathrm{N}-1.5$ 区) $2.9 \%, 3.0 \mathrm{~g}$ 区 (N-3.0区) $3.4 \% ， 6.0 \mathrm{~g}$ 区 (N-6.0区) 3.8\%と窒素 施肥量の增加とともに高まった．多窒素区と比較して， $\mathrm{N}-0$ 区の葉は薄く，小さく，葉は黄色がかっていた。 単位葉面積当たりのクロロフィル含量は窒素施肥量の 低下とともに隇少した，葉内デンプン含量は多窒素区
に比べて，無絰素区で顕著に高かった。アミラーゼ活 性は葉のデンプン含量と対応しており，デンプン含量 の低い多窒素区（N-3.0区と N-6.0区）がデンプン 含虹の高い無窒素区より明らかに高かった。無窒素区 の葉緑体の核㥞体は，葉緑体内にデンプンが蓄積する とともに葉緑体の周辺部に局在するのに対し，デンプ ン粒の小さい多等素区では核梯体は葉緑体中に一様に 分布した，単位葉面積当たりの光合成速度は無窒素区 が最も低く，䇪素施肥によって增加したが，窒素施肥 区間での相違怔認められなかった。 